\title{
A BÖLCSŐDEI ELLÁTÁS ÉS A CSALÁDI NAPKÖZI VÁLASZTÁSÁNAK ALAKULÁSA 2006-2016 KÖZÖTT
}

\author{
Szerzők: \\ Mező Ferenc (Ph.D) \\ Eszterházy Károly Egyetem (Magyarország) \\ Mező Katalin (Ph.D) \\ Debreceni Egyetem (Magyarország)
}

Első szerző e-mail címe:

ferenc.mezo1@gmail.com

\author{
Lektorok: \\ Szerepi Sándor (Ph.D) \\ Debreceni Egyetem (Magyarország) \\ Szabóné Balogh Ágota (Ph.D) \\ Gál Ferenc Egyetem (Magyarország) \\ ...és további két anonim lektor
}

Mező Ferenc és Mező Katalin (2020): A bölcsödei ellátás és a családi napközi választásának alakulása 2006-2016 kö̊ött. Különleges Bánásmód, VI. évf. 2020/4. szám, 19-28. DOI 10.18458/KB.2020.4.19

\begin{abstract}
Absztrakt
E tanulmány célja, hogy feltárja a 2006-2016 közötti időszakban múködő bölcsődék ( $n=543-755)$ és családi napközik ( $n=60-1195)$ számbeli, illetve a gyermekek létszáma $(n=1313960)$ szerinti együttjárásokat. A vizsgálat szekunder adatgyújtést (a Központi Statisztikai Hivatal által nyilvánossá tett adatokat) alkalmazott az adatelemzés előkésztése érdekében. Eredményeink erős rang-korrelációk $\left(r_{s}>0,9 ; p \leq 0,05\right)$ mutatnak az évszámok, a bölcsődék és családi napközik, továbbá az ezekbe beíratott gyermekek száma között.
\end{abstract}

Kulcsszavak: bölcsőde, családi napközi

Diszciplinák: pedagógia, pszichológia

\begin{abstract}
CHANGING OF CHOICES OF DAY-NURSERY AND FAMILY CARE AMONG THE YEARS 2006-2016

The aim of this study is to explore the correlations between the number of day-nurseries $(n=543-755)$ and family daycare $(n=60-1195)$ operating between 2006 and 2016, as well as the number of children $(n=$ 1313960). The study used secondary data collection (data made public by the Central Statistical Office) to prepare for data analysis. Our results show strong rank correlations $\left(r_{s}>0,9 ; p \leq 0,05\right)$ among the years and the number of day-nurseries and family daycares, and the number of children enrolled in these.
\end{abstract}

Keywords: day-nursery, family daycare

Disciplines: pedagogy, psychology 
A 2006-2016 közötti években Magyarországon a családban nevelkedô gyermek sorsa 20 hetes korától 3 éves koráig a legjellemzőbb módon a következőképpen alakulhatott: a családi otthonban nevelték (ami kiegészülhetett akár házi gyermekfelügyelettel is), bölcsődei (hetes bölcsőde esetében akár bentlakásos formában történő) ellátásban részesült vagy családi napközibe íratták be szülei.

A gyermek saját háztartásban nevelése alkalmával a szülő (rendszerint az anya), gondviselő nevelte a gyermeket a családi szocializáció keretén belül. „A gyermek első természetes környezete a család. A család - társadalmi egység, mely életformájával, légkörével megalapozza, erősen befolyásolja a gyermek testi-lelki egészségét, erkölcsi fejlődését, jellemét." (Tardos, 1975, 60.). Megjegyezzük, hogy a potenciális szülóknek tanköteles korukban kötelező volt ugyan a közoktatásban részt venni, ám arra korábban sem volt példa és napjainkban sem jellemző, hogy professzionális felkészítést nyújtson a tanulók (mint jövőbeli szülők) számára a csecsemő- és kisgyermeknevelés terén. Ennélfogva egy családban nevelkedő - ideális esetben sok szülői odafigyelést, szeretett kapó - gyermek nem feltétlenül kapta meg azt a fajta ellátást, mint a bölcsődében nevelkedő társai (a társas élményről nem is beszélve).

A vizsgált időszakban adott volt a házi gyermekfelügyelet jellegú ellátási forma is, amely sajátos keveréke volt a család otthonában történő, mégis gyermeknevelésre képzett szakember általi gondozásnak: a gondozó a család otthonában végezte a gyermek gondozását. „A házi gyermekfelügyelet alapvető feladata, hogy a dolgozó, vagy a magára maradt szülőt segítse a gyermek időszakos otthoni felügyelete, gondozása biztositásával. A szolgáltatás nem csak a rászoruló szülōt segíti, hanem társadalmi hasznossága tekintetében: 1) egy szükséglethez igazodó szolgáltatást jelent; 2) igénybevételével fenntartható a család munkaerő-piaci, társadalmi aktivitása" (Kovácsné és tsai, 2012, 4.).
Speciális esetnek tekinthető még a szakképzett gyermeknevelő általi és a családi környezetben történő nevelésnek az a sajátos keresztmetszete, ami alkalmával a gyermeket nevelő szülő bölcsődei gondozónő is volt egyben.

A bölcsődében a családi szocializáció kiegészül az intézmény szocializációs hatásaival, ami részben megtervezett pedagógiai jellegú, részben azonban még így is véletlenszerű, és a kortársak hatásai által is befolyásolt. A bölcsődei nevelés célját a bölcsődei nevelés-gondozás szakmai szabályaiban (Baloghné és tsai, 2012, 16-17.) a következőképp határozták meg: „a családban nevelkedő kisgyermek számára a családi nevelést segítve, napközbeni ellátás keretében a gyermek fizikai- és érzelmi biztonságának és jóllétének megteremtésével, feltétel nélküli szeretettel és elfogadással, a gyermek nemzetiségi/etnikai hovatartozásának tiszteletben tartásával, identitásának erősítésével, kompetenciájának figyelembevételével, tapasztalatszerzési lehetőség biztosításával, viselkedési minták nyújtásával elősegíteni a harmonikus fejlődést".

Főiskolai szintű kisgyermeknevelő-képzés 2009től történik hazánkban (Gyöngy, 2013), a 2009 előtti időszakban tehát nem volt jellemzó ilyen jellegú diplomával rendelkező szakember a bölcsődékben. 2016-ra azonban a korábban jellemző szakirányú OKJ-s végzettség vagy felsőoktatási szakképesítés (FOKSZ) háttérbe szorult a 6 féléves Csecsemő- és kisgyermeknevelő (BA) alapképzéssel szemben, mely révén a diplomás csecsemő- és kisgyermeknevelők bekapcsolódhattak a pedagógus életpályamodellbe.

A bölcsődei nevelést szabályozó jogi környezetből érdemes kiemelni, hogy a (jelen tanulmányban vizsgált időintervallum végén megjelenésre kerülő) 6/2016. (III. 24.) EMMI (Emberi Erőforrások Minisztériuma által kiadott) rendelet 4. melléklete váltotta fel a (vizsgálati időintervallumunkat nyolc évvel megelőzô) személyes gondoskodást nyújtó gyermekjóléti, gyermekvédelmi intézmények, valamint 
személyek szakmai feladatairól és múködésük feltételeiről szóló 15/1998. (IV. 30.) NM (Népjóléti miniszter által kiadott) rendelet 10. mellékletét - ezek témája: a bölcsődei nevelés-gondozás alapprogramja.

Balogh és tsai (2012) a bölcsődei nevelésgondozás országos alapprogramjával kapcsolatban (vesd össze: Szombathelyiné és tsai, 2008) felhívta a figyelmet az Egyesült Nemzetek Szervezete (ENSZ) Emberi jogok nyilatkozata, az ENSZ Egyezmény a gyermek jogairól és az Európa Tanács Miniszterek Bizottsága Rec. (2002) 8-as ajánlása a tagállamok számára a napközbeni gyermekellátásról címú dokumentumokra. Ezeken kívül a hazai bölcsődei nevelés történeti és aktuális szabályozása tekintetében az alábbi törvények, kormány- és miniszteri rendeletek a mérvadók:

\section{Törvények:}

• 1992. évi XXXIII. törvény a közalkalmazottak jogállásáról.

- 1993. évi XCIII. törvény a munkavédelemről.

- 1993. évi LXXIX. törvény a közoktatásról.

- 1995. évi XXVIII. törvény a nemzeti szabványosításról.

- 1997. évi XXXI. törvény a gyermekek védelméről és a gyámügyi igazgatásról.

- 2011. évi CXCV. törvény az államháztartásról.

- 2011. évi CXII. törvény az információs önrendelkezési jogról és az információszabadságról.

\section{Kormányrendeletek:}

- 20/1997. (II.13.) Kormányrendelet a közoktatásról szóló 1993. évi LXXIX. törvény végrehajtásáról.

- 235/1997. (XII.17.) Kormányrendelet a gyámhatóságok, a területi gyermekvédelmi szakszolgálatok, a gyermekjóléti szolgálatok és a személyes gondoskodást nyújtó szervek és személyek által kezelt személyes adatokról.

- 253/1997. (XII.20.) Kormányrendelet az országos településrendezési és építési követelményekről.

- 257/2000. (XII. 26.) Kormányrendelet a közalkalma- zottak jogállásáról szóló 1992. évi XXXIII. törvénynek a szociális, valamint a gyermekjóléti és gyermekvédelmi ágazatban történő végrehajtásáról.

- 259/2002. (XII.18.) Kormányrendelet a gyermekjóléti és gyermekvédelmi szolgáltatótevékenység engedélyezéséről, valamint a gyermekjóléti és gyermekvédelmi vállalkozás engedélyezéséről.

- A személyes gondoskodást nyújtó gyermekjóléti alapellátások és gyermekvédelmi szakellátások térítési díjáról és az igénylésükhöz felhasználható bizonyítékokról szóló 328/2011. (XII. 29.) Korm. rendelet.

Miniszteri rendeletek:

- 63 /1997. (XII. 21.) NM rendelet a fertőző betegségek jelentési rendjéről.

- 15/1998. (IV. 30.) NM rendelet a személyes gondoskodást nyújtó gyermekjóléti, gyermekvédelmi intézmények, valamint személyek szakmai feladatairól és múködésük feltételeirôl.

- 18/1998. (VI.3.) NM rendelet a fertőző betegségek és a járványok megelőzése érdekében szükséges járványügyi intézkedésekről.

- 33/1998. (VI. 24.) NM rendelet a munkaköri, szakmai ill. személyi alkalmasság orvosi vizsgálatáról és véleményezéséről.

- 8/2000. (VIII. 4.) SzCsM rendelet a személyes gondoskodást végző személyek adatainak működési nyilvántartásba vételéről.

- 9/2000. (VIII. 4.) SzCsM rendelet a személyes gondoskodást végző személyek továbbképzésérôl és a szociális szakvizsgáról.

- 78/2003. (XI. 27.) GKM rendelet a játszótéri eszközök biztonságosságáról.

- 4/2010. (I. 19.) OKM rendelet a pedagógiai szakszolgálatokról.

- 62/2011. (VI. 30.) VM rendelet a vendéglátóipari termékek előállításának és forgalomba hozatalának élelmiszerbiztonsági feltételeiről.

• 6/2016. (III. 24.) EMMI rendelet a személyes gondoskodást nyújtó gyermekjóléti, gyermekvédelmi intézmények, valamint személyek szakmai feladatairól és működésük feltételeirôl szóló 15/1998. (IV. 30.) NM rendelet módosításáról 
A gyermekjóléti alapellátás részeként a szülő dönthetett úgyis, hogy családi napközibe (vö.: Kovácsné és tsai, 2013) íratja be bölcsődés korú gyermekét, ahol családias környezetben, kis létszámú csoportban történhetett meg a gyermek napközbeni gondozása, nevelése (20 hetes kortól akár 14 éves korig).

A családi napközi nem minősült intézménynek, így létezésére és múköodtetésére is más feltételek vonatkoztak, mint az intézmények esetében (múködése azonban engedélyhez kötött volt). Ennek az ellátási formának a szülők számára előnyös tulajdonsága lehetett, hogy:

a) rugalmasan tudott igazodni a szülők időbeosztásához,

b) kis létszámú gyermekcsoportokat alakíthatott ki,

c) a gyermekek egyéni szükségleteire fókuszálhatott.

A családi napköziben a gyermekekkel dolgozó személyeknek nem kellett szakirányú végzettséggel rendelkezniük, de tanfolyamot el kellett végezniük - vö.: 29/2003. (V. 20.) ESzCsM (Egészségügyi, szociális és családügyi miniszter által kiadott) rendelet. A családi napközi múködését meghatározó jogszabályok:

Törvények:

- 1993. évi XCIII. törvény a munkavédelemről;

- 1999. évi XLII. törvény a nemdohányzók védelméről és a dohánytermékek fogyasztásának és forgalmazásának szabályairól;

- 2000. évi XXV. törvény a kémiai biztonságról;

-1995. évi XXVIII. törvény a nemzeti szabványosításról;

- 1997. évi XXXI. törvény a gyermekek védelméről és a gyámügyi igazgatásról;

- 2011. évi CXC. törvény a nemzeti köznevelésrôl;

- 2011. évi CXCV. törvény az államháztartásról;

- 2011. évi CCXI. törvény a családok védelmérôl;
- 2011. évi CXII. törvényt az információs önrendelkezési jogról és az információszabadságról

- mindenkori költségvetési törvény.

Kormányrendeletek:

-235/1997. (XII. 17.) Kormányrendelet a gyámhatóságok, a területi gyermekvédelmi szakszolgálatok, a gyermekjóléti szolgálatok és a személyes gondoskodást nyújtó szervek és személyek által kezelt személyes adatokról;

-253/1997. (XII. 20.) Kormányrendelet az országos településrendezési és építési követelményekról;

-257/2000. (XII. 26.) Kormányrendelet a közalkalmazottak jogállásáról szóló 1992. évi XXXIII. törvénynek a szociális, valamint a gyermekjóléti és gyermekvédelmi ágazatban történő végrehajtásáról;

- 259/2002 (XII. 18.) Kormányrendelet a gyermekjóléti és gyermekvédelmi szolgáltatótevékenység engedélyezéséról, valamint a gyermekjóléti és gyermekvédelmi vállalkozás engedélyezéséről;

- 226/2006. (XI. 20.) Kormányrendelet a szociális, gyermekjóléti és gyermekvédelmi szolgáltatók, intézmények ágazati azonosítójáról és országos nyilvántartásáról;

-213/2009. (IX. 29.) Kormányrendelet az egyházi és nem állami fenntartású szociális, gyermekjóléti és gyermekvédelmi szolgáltatók normatív állami fenntartásáról;

- 328/2011. (XII. 29.) Kormányrendelet a személyes gondoskodást nyújtó gyermekjóléti alapellátások és gyermekvédelmi szakellátások térítési dijáról és az igénylésükhöz felhasználható bizonyitékokról;

-331/2010. (XII. 27.) Kormányrendelet a Nemzeti Rehabilitációs és Szociális Hivatalról, valamint eljárásának részletes szabályairól.

Miniszteri rendeletek:

- 8/1981. (XII. 27.) IpM rendelet a Kommunális- és Lakóépületek Érintésvédelmi Szabályzatáról;

- 15/1998. (IV. 30.) NM rendelet a személyes gondoskodást nyújtó gyermekjóléti, gyermekvédelmi intézmények, valamint személyek szakmai feladatai- 
ról és működésük feltételeiről;

- 33/1998. (VI. 24.) NM rendelet a munkaköri, szakmai, illetve személyi higiénés alkalmasság orvosi vizsgálatáról és véleményezéséről;

- 25/2000. (IX. 30.) EüM-SzCsM együttes rendelet a munkahelyek kémiai biztonságáról.

- 44/2000. (XII. 27.) EüM rendelet a veszélyes anyagokkal és a veszélyes készítményekkel kapcsolatos egyes eljárások, illetve tevékenységek részletes szabályairól;

- 3/2002. (II. 8.) SzCsM-EüM együttes rendelet a munkahelyek munkavédelmi követelményeinek minimális szintjéről;

- 29/2003. (V. 20.) ESzCsM rendelet a helyettes szülők, a nevelőszülők, a családi napközit múködtetők képzésének szakmai és vizsgakövetelményeiről, valamint az örökbefogadás előtti tanácsadásról és felkészítő tanfolyamról; • 78/2003. (XI. 27.) GKM rendelet a játszótéri eszközök biztonságosságáról;

- 28/2011.(IX.6) BM rendelet az Országos Tűzvédelmi Szabályzatról.

Az Emberi Erőforrások Minisztérium 6/2016. (III. 24.) EMMI rendelete módosítja a személyes gondoskodást nyújtó gyermekjóléti, gyermekvédelmi intézmények, valamint személyek szakmai feladatairól és múködésük feltételeirôl szóló 15/1998. (IV. 30.) NM rendeletet. 2017. január 1tôl a bölcsődei ellátást érintő alapvető változások következtek be, mely reform keretében a napközbeni gyermekellátás intézményi (bölcsőde, mini bölcsőde), illetve szolgáltatás (családi bölcsőde, munkahelyi bölcsőde, napközbeni gyermekfelügyelet) jellegú formában valósulhat meg.

Jelen tanulmányban a bölcsődei nevelés egy lezártnak tekinthető, a 2006-2016 közötti évekkel határolt bő évtizedes időszakának elemzése során a bölcsődék és családi napközik számának alakulását, illetve az ezekbe beíratott gyermekek számának alakulását elemezzük.

\section{Kérdések és hipotézisek}

Jelen tanulmányban az alábbi kérdésekre keressük a választ:

1. A 2006-2016 közötti időszakban megfigyelhető-e a bölcsődék és a családi napközik számanak növekedése? Hipotézisünk szerint a bölcsődék és a családi napközik száma erős korrelációt mutat az évszámmal.

2. Vajon az évek múlásával együtt jár a bölcsődébe, családi napközibe beíratott, illetve be nem íratott gyermekek száma? Feltételezésünk szerint erős pozitív korreláció mutatkozik az évszám és a bölcsődében, családi napköziben nevelt gyermekek száma között, s negatív korreláció lesz tapasztalható az intézményes nevelés említett formáiba be nem íratott gyermekek száma között (többek között a módszertani részben bemutatott képlet alapján feltételezhető, hogy ha a bölcsődébe/családi nevelésbe beíratott gyermekek száma növekvő tendenciát mutat, akkor a többieké csökkenni fog).

\section{Minta}

Az alábbiakban egyrészt a 2006-2016 évek közötti 11 évben múködő bölcsődéket $(n=543-755)$, illetve családi napköziket ( $n=60-1195)$, másrészt a 0-3 éves gyermekeket ( $n=1313$ 960) vizsgáljuk abból a szempontból, hogy bölcsődei, családi napközibeli vagy egyéb (leginkább: családban, otthon) nevelésben részesültek-e. A vizsgálat során - szekunder adatgyújtés keretében - a Központi Statisztikai Hivatal (KSH) hivatalos, nyilvános adatbázisait használtuk, melyek a www.ksh.hu oldalon keresztül érhetők el.

A bölcsődébe és/vagy családi napközibe beíratott gyermekek száma a KSH hivatalos, nyilvános adatbázisából áll rendelkezésre. Mivel a bölcsődei, illetve családi napközibeli nem részesült gyermekek számáról nem tartalmazott közvetlen adatot az említett adatbázis, így azt becsléssel állapítottuk meg. A bölcsődei, illetve családi napközibeli nevelésben 
nem részesülő gyermekek számának kalkulációja során az élveszületések becsült számából vontuk ki a bölcsődébe és családi napközibe beíratott gyermekek számát. Hangsúlyozzuk, hogy így becsült értéket kaptunk. 2006-2016 között 1026680 élveszületés történt, amihez hozzáadtuk a 20032005 közötti élveszületések (97 496, 95137 és 94647 fó) számát, akik a 2006-2016 években 1,2, illetve 3 évesként bölcsődés korúnak tekinthetők, s így kaptuk meg a mintának tekintett $n=1313960$ fót. Sajnos ez a szám túlbecsült, mert (adathiány miatt) nem veszi figyelembe a $0-3$ éves korúakra az adott időszakban jellemző gyermekhalandóságot, illetve emigrációs/migrációs tendenciákat (például: egy magyar család bölcsődés korú gyermekkel együtt történő külföldre költözését, vagy egy külföldi család bölcsődés korú gyermekkel együtt történő hazai letelepedését).

\section{Módszer}

E tanulmány retrospektív jelleggel a 2006-2016 közötti időszakra fókuszál, mely időszakkal kapcsolatban lehetôség adódott (szekunder adatgyüjtés révén) a Központi Statisztikai Hivatal által összeállított publikus adatbázisok elemzésére. Primer adatgyújtésre nem került sor jelen vizsgálat keretében.

A Központi Statisztikai Hivatal, mint szakmailag önálló kormányhivatal, immár 150 éves múltra tekint vissza, és feladatai közé tartozik ,az adatfelvételek megtervezése, adatok felvétele, feldolgozása, tárolása, elemzése és közzététele" (lásd: http://www.ksh.hu/tevekenyseg_kozerdeku) is többek között a bölcsődei és családi napközibeli ellátás, illetve az élveszületések terén is. Adatbázisai a www.ksh.hu oldalon keresztül érhetók utol. Jelen tanulmányban használt adatbázisok letöltése 2020. szeptember 2-án történt.
Jelen tanulmányban a következő vizsgálati változókra fókuszáltunk:

- Bölcsődék száma: a KSH nyilvántartásában tárgyévente szereplő múködő, bölcsődék száma.

- Családi napközik száma: a KSH nyilvántartásában tárgyévente szereplő, múködő családi napközik száma.

- Bölcsődébe beíratott gyermekek száma: a KSH nyilvántartása szerint, tárgyév május 31-i adatok alapján.

- Családi napközibe beíratott gyermekek száma: a KSH nyilvántartása szerint, tárgyév május 31-i adatok alapján.

- Egyéb (például otthonnevelésben részesülő) gyermekek becsült száma. Ezt a számot tárgyévenként az A = B - $(C+D+E)$ képlet alapján kalkuláltuk, ahol:

A = az egyéb (pl. otthonnevelésben része-

sülô) gyermekek becsült száma;

$\mathrm{B}=$ az élveszületések száma

$\mathrm{C}=\mathrm{a}$ bölcsődébe beíratott gyermekek

száma;

$\mathrm{D}=$ a családi napközibe íratott gyermekek száma.

$\mathrm{E}=$ bölcsődéskorúak halálozásából, illetve a migrációból, emigrációból eredő 0-3 éves gyermekszám változás ismeretlen értéke.

Tekintve, hogy az E-értékkel kapcsolatban nem rendelkezünk adatokkal, ezért az bölcsődén és családi napközin kívüli egyéb nevelésben részesülő gyermekek számának mindössze becslésével kalkulálhatunk a vizsgálat során, $\mathrm{s}$ jobb híján az $\mathrm{E}=0$ értéket alkalmazzuk, $\mathrm{s}$ inkább csak figyelemfelhívásképpen említjük az E-értékben rejló bizonytalanságot. Abban bízunk azonban, hogy a trendeket tekintve mindez nem befolyásolja számottevően a vizsgálati eredményeket. 
$\mathrm{Az}$ adatelemzés során használt csoportositó változó az „Év” volt, ami a 2006-2016 között eltelt 11 év évszámait tartalmazta.

A leíró statisztikát, Kolmogorov-Smirnov-próbát, Spearman-féle rangkorreláció számítást alkalmazó adatelemzéshez az SPSS 13.0 statisztikai szoftvert használtuk.

\section{Eredmények}

Az ellátó belyek számával kapcsolatos hipotézis alátámasżtást nyert. Erős, pozitív irányú szignifikáns együttjárás tapasztalható az évszám (2006-2016 között), a bölcsődék és a családi napközik száma között $\left(r_{s}=0,99, p \leq 0,01\right)$.

Amint az 1. ábrán látható a családi napközik száma intenzívebb növekedést mutat, mint a bölcsődék számának alakulása. A 2006-os kiinduló értékhez képest a családi napközik száma 2016-ra közel 20-szorosára nőtt (60-ról 1 195-re, szorzó = 19,92), míg a bölcsődék száma csak mintegy másfélszeresére emelkedett (543-ról 755-re, szorzó $=1,39) !$ A családi napközik száma 2010-ben emelkedett a bölcsődék száma fölé, s az után is növekedett a számuk, bár egyre kisebb mértékben. A bölcsődék száma lassabb ütemben, de egyenletesebb mértékben nőtt az évek során.

Beíratással kapcsolatos eredmények. Erős, pozitív irányú szignifikáns együttjárás tapasztalható az évszám (2006-2016 között), a bölcsődébe és a családi napközibe beíratott gyermekek száma között $\left(r_{s}\right.$ $=0,99$ és 0,95 között, $p \leq 0,01$ ), ezzel szemben az egyéb (pl. otthon nevelés) ellátási forma és az évszám között erős negatív korreláció tapasztalható $\left(r_{s}=-0,93, p \leq 0,01\right)$. A 2006-2016 közötti időszakban minden évben jellemző volt, hogy a bölcsődés korú gyermekek több, mint $80 \%$-a otthon nevelkedett.

1. ábra: A müködö bölcsódék és családi napközile számának alakulása 2006-2016 között (forrás: KSH adatok alajján a Szerzó)

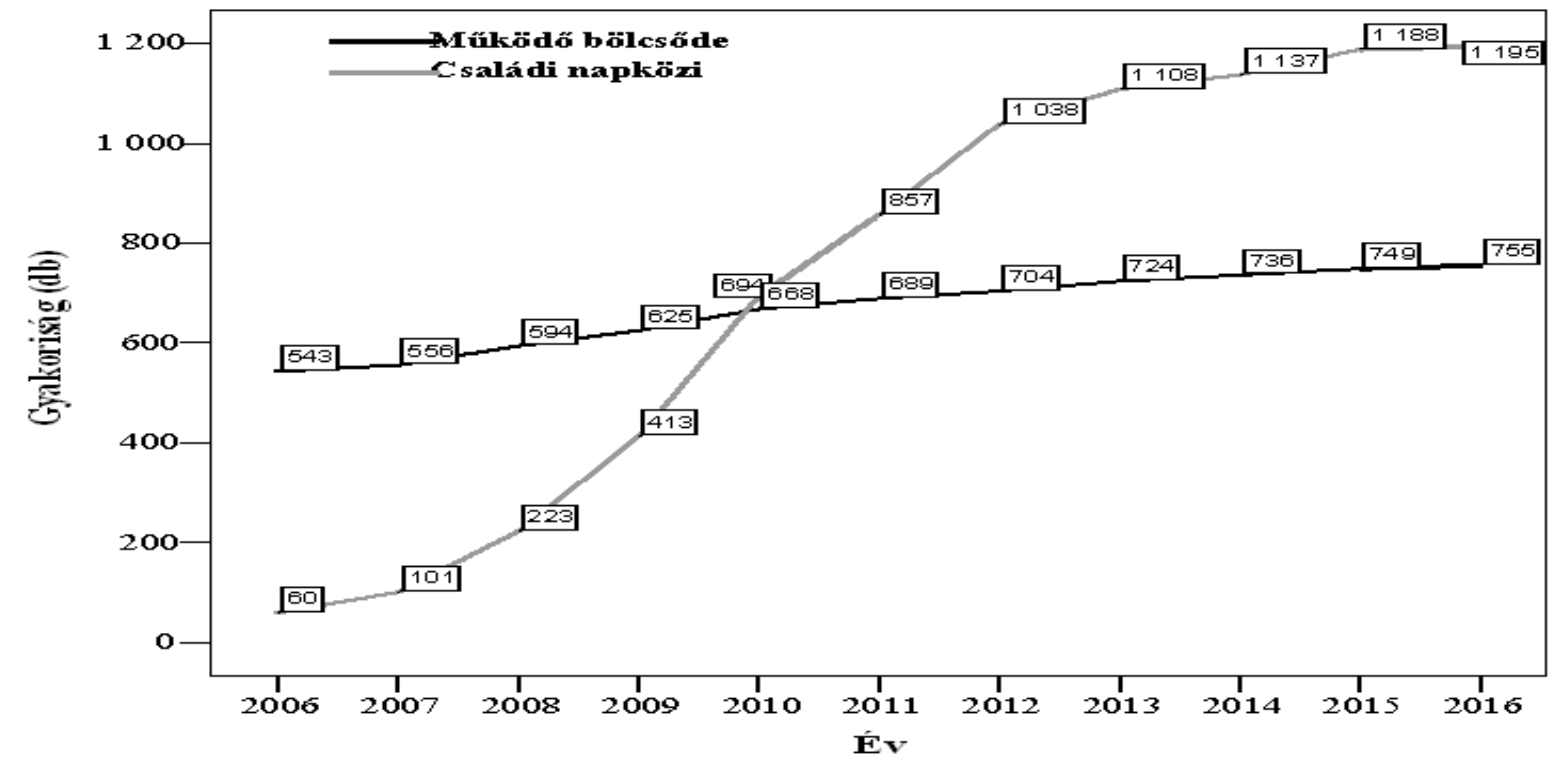




\section{Megvitatás}

Az ellátó helyek számának alakulásával kapcsolatos eredmények alapján úgy tűnik, hogy a 0-3 éves gyermekek nevelését feladatul vállaló bölcsődék és családi napközik létrehozását és fenntartását facilitáló intézkedések valóban jelentős eredményeket tudtak felmutatni a vizsgált években. Ugyanakkor szembeötlő, hogy a bölcsődék és a családi napközik számának növekedése igen különböző mértékú (vö.: 1. ábra).

A családi napközik számának intenzívebb alakulásának hátterében a következő (egymást nem kizáró okok állhattak):

a) Könnyebb volt létrehozni családi napközit, mint bölcsődét;

b) Könnyebb volt fenntartani családi napközit, mint bölcsődét;

c) Könnyebb volt támogatást kapni a családi napközi esetében, mint a bölcsőde esetében;

d) A családi napközi fenntartása esetében a bevétel-kiadás-nyereség triász kedvezőbben alakul, mint a bölcsődék fenntartása esetében;

e) Családi napközi fenntartói köre tágabb lehetett, mint a bölcsődék fenntartói köre;

f) Nagyobb szülói igény mutatkozott a családi napközi iránt, mint a bölcsőde iránt: előfordulhat, hogy amennyiben egy szülőnek választási lehetôsége volt abban a tekintetben, hogy gyermekét bölcsődébe vagy családi napközibe írassa, akkor az utóbbit választja. A szülők felől megnyilvánuló családi napközi iránti kereslet pedig lokálisan (egy adott település vagy településrész tekintetében) piaci kínálatot generálhatott, amennyiben a keresletet felismerô szolgáltatók családi napközit hoztak létre. Jelenleg nem állnak rendelkezésünkre e feltételezést alátámasztó adatok, ám a későbbiekben ezek összegyújthetók primer adatgyúitést alkalmazó kérdôíves, interjús felmérések keretében;

g) A családi napközibeli ellátás elérhetőbb volt a családok számára, mint a bölcsődei ellátás;

h) A szülők nézőpontjából a családi napközibeli ellátás talán egyenértékủ vagy vonzóbb, mint a bölcsődei ellátás.

A beiratással kapcsolatos eredményeket tekintve feltűnő, hogy noha mind a bölcsődébe, mind a családi napközibe beíratott gyermekek száma mutatott némi emelkedést az évek során (31153-ról 38123-ra nőtt a bölcsődébe íratott gyermekek száma, s néhány százról 7099-re a családi napközibe íratott gyermekek száma), mégis az egyéb (például az otthonnevelés) ellátási forma maradt a domináns gyermeknevelési lehetôség az adott időszakban. Ennek okai talán a következők lehettek:

a) kielégítetlen szülői igény a bölcsődék, családi napközik iránt: ha feltételezzük, hogy létezett tömegesen megnyilvánuló szülói igény a bölcsődei, illetve a családi napközik iránt, akkor e lehetőségek növekvő, ám folyamatosan a potenciális igények alatt maradó száma lehetett az oka annak, hogy a szülők kénytelenek voltak például az otthon nevelést választani. $\mathrm{E}$ feltételezés teljesülése esetében a bölcsődei és a családi napközi jellegú ellátás számának intenzív növelése valóban indokolt lehetett. Egy ilyen jellegű „intézményfejlesztési cunami”" egyrészt munkahelyet teremthetett (direkt módon a csecsemó- és kisgyermeknevelők számára, indirekt módon a bölcsődéknek, családi napköziknek szolgáltatók számára), másrészt több ezer szülőnek tehette lehetôvé az aktív munkavállalói létet. Egy 12 gyermek/gondozó arányt jelentő bölcsődében például 20000 lehetséges munkahely értéket kapjuk.

b) nem létezett valódi szülői igény a bölcsődék, családi napközik iránt: ha azt feltételezzük, hogy nem volt valódi szülói igény a bölcsődei, illetve családi napközi jellegú ellátás iránt, akkor e számok az otthon nevelés szülók által történő preferálást, s az otthon nevelést lehetővé tevő családsegítő intézkedések iránti igényt jelzik.

Hangsúlyozzuk, hogy az adatok a 2006-2016 közötti időszakra vonatkoznak. 2017. január 1-től a 3 éven aluli gyermekek ellátásának megnevezése: „Gyermekek napközbeni ellátása”, melynek megvalósulhat a bölcsődei ellátás intézményi (bölcsőde, 
illetve mini bölcsőde) és szolgáltatási (családi bölcsőde és munkahelyi bölcsőde) formájában (Dudás, 2019; v.ö.: 6/2016. (III. 24.) EMMI rendelet).

\section{Korlátok, további kutatási lehetőségek}

A bölcsődei és a családi napközi jellegú ellátáson kívüli egyéb (pl. otthonnevelés jellegü) ellátás esetében csak becsült számadatokkal rendelkezünk, ezért a jövőben pontos számadatokkal célszerú kiegészíteni a vizsgálatot.

A kutatás során szekunder adatgyüjtés révén alakult ki az adatbázis, de az eredmények értékelésekor, megvitatásakor is kitűnt, hogy a jövőben primer adatgyújtésen alapuló elemzésre is szükség lehet.

A kutatás eredményeinek megvitatásakor több, alátámasztásra váró felvetést is körvonalaztunk, miközben a lehetséges okokat igyekeztünk összefoglalni. E feltevések alátámasztása érdekében további kutatásokra van szükség.

A vizsgálat egy komplex vizsgálatsorozat előtanulmányának tekinthető, amely arra keresi a választ, hogy a 2017-től jellemző bölcsődei ellátás valóban előnyökkel jár-e a gyermekek kognitív és non-kognitív fejlódése tekintetében.

\section{Irodalom}

15/1998. (IV. 30.) NM rendelet a személyes gondoskodást nyújtó gyermekjóléti, gyermekvédelmi intézmények, valamint személyek szakmai feladatairól és múködésük feltételeiről.

18/1998. (VI.3.) NM rendelet a fertőző betegségek és a járványok megelőzése érdekében szükséges járványügyi intézkedésekről.

1992. évi XXXIII. törvény a közalkalmazottak jogállásáról.

1993. évi LXXIX. törvény a közoktatásról.
1993. évi XCIII. törvény a munkavédelemről. 1995. évi XXVIII. törvény a nemzeti szabványosításról.

1997. évi XXXI. törvény a gyermekek védelmérôl és a gyámügyi igazgatásról.

1999. évi XLII. törvény a nemdohányzók védelméről és a dohánytermékek fogyasztásának és forgalmazásának szabályairól;

20/1997. (II.13.) Kormányrendelet a közoktatásról szóló 1993. évi LXXIX. törvény végrehajtásáról.

2000. évi XXV. törvény a kémiai biztonságról;

2011. évi CCXI. törvény a családok védelmérôl;

2011. évi CXC. törvény a nemzeti köznevelésről;

2011. évi CXCV. törvény az államháztartásról.

2011. évi CXII. törvény az információs önrendelkezési jogról és az információszabadságról.

213/2009. (IX. 29.) Kormányrendelet az egyházi és nem állami fenntartású szociális, gyermekjóléti és gyermekvédelmi szolgáltatók normatív állami fenntartásáról;

226/2006. (XI. 20.) Kormányrendelet a szociális, gyermekjóléti és gyermekvédelmi szolgáltatók, intézmények ágazati azonosítójáról és országos nyilvántartásáról;

235/1997. (XII. 17.) Kormányrendelet a gyámhatóságok, a területi gyermekvédelmi szakszolgálatok, a gyermekjóléti szolgálatok és a személyes gondoskodást nyújtó szervek és személyek által kezelt személyes adatokról;

25/2000. (IX. 30.) EüM-SzCsM együttes rendelet a munkahelyek kémiai biztonságáról.

253/1997. (XII. 20.) Kormányrendelet az országos településrendezési és építési követelményekről;

257/2000. (XII. 26.) Kormányrendelet a közalkalmazottak jogállásáról szóló 1992. évi XXXIII. törvénynek a szociális, valamint a gyermekjóléti és gyermekvédelmi ágazatban történő végrehajtásáról.

259/2002 (XII. 18.) Kormányrendelet a gyermekjóléti és gyermekvédelmi szolgáltatótevékenység engedélyezéséről, valamint a 
gyermekjóléti és gyermekvédelmi vállalkozás engedélyezéséről;

28/2011.(IX.6) BM rendelet az Országos Tûzvédelmi Szabályzatról.

29/2003. (V. 20.) ESzCsM rendelet a helyettes szülők, a nevelőszülők, a családi napközit múködtetők képzésének szakmai és vizsgakövetelményeiről, valamint az örökbefogadás elôtti tanácsadásról és felkészítő tanfolyamról;

3/2002. (II. 8.) SzCsM-EüM együttes rendelet a munkahelyek munkavédelmi követelményeinek minimális szintjéról;

328/2011. (XII. 29.) Kormányrendelet a személyes gondoskodást nyújtó gyermekjóléti alapellátások és gyermekvédelmi szakellátások térítési díjáról és az igénylésükhöz felhasználható bizonyítékokról;

33/1998. (VI. 24.) NM rendelet a munkaköri, szakmai ill. személyi alkalmasság orvosi vizsgálatáról és véleményezéséről.

331/2010. (XII. 27.) Kormányrendelet a Nemzeti Rehabilitációs és Szociális Hivatalról, valamint eljárásának részletes szabályairól.

4/2010. (I. 19.) OKM rendelet a pedagógiai szakszolgálatokról.

44/2000. (XII. 27.) EüM rendelet a veszélyes anyagokkal és a veszélyes készítményekkel kapcsolatos egyes eljárások, illetve tevékenységek részletes szabályairól;

6/2016. (III. 24.) EMMI rendelet a személyes gondoskodást nyújtó gyermekjóléti, gyermekvédelmi intézmények, valamint személyek szakmai feladatairól és múködésük feltételeiről szóló 15/1998. (IV. 30.) NM rendelet módosításáról

62/2011. (VI. 30.) VM rendelet a vendéglátóipari termékek elóállításának és forgalomba hozatalának élelmiszerbiztonsági feltételeiről.

63 /1997. (XII. 21.) NM rendelet a fertőző betegségek jelentési rendjéről.
78/2003. (XI. 27.) GKM rendelet a játszótéri eszközök biztonságosságáról.

8/1981. (XII. 27.) IpM rendelet a Kommunális- és Lakóépületek Érintésvédelmi Szabályzatáról;

8/2000. (VIII. 4.) SzCsM rendelet a személyes gondoskodást végző személyek adatainak múködési nyilvántartásba vételéről.

9/2000. (VIII. 4.) SzCsM rendelet a személyes gondoskodást végző személyek továbbképzésérôl és a szociális szakvizsgáról.

Balogh Lászlóné, Barbainé Bérci Klára, Kovácsné Bárány Ildikó, Nyitrai Ágnes, Dr. Rózsa Judit, Tolnayné Falusi Mária és Vokony Éva (2012): A bölcsódei nevelés-gondozás szakmai szabályai. Módszertani levél. Nemzeti Család- és Szociálpolitikai Intézet, Budapest.

Dudás Ágnes (2019): Bölcsődei ellátás. Letöltés: 2020-08-25- Web: https://csalad.hu/ tamogatasok/bolcsodei-ellatas

Gyöngy Kinga (2013): Milyen az ideális kisgyemeknevelő. Letöltés: 2020.08.25. Web: http://www.kre.hu/ebook/dmdocuments/ii_o rszagos alkalmazott pszichologiai phd hallgatoi konferencia/chap 14.html

Kovácsné Bárány Ildikó, Mátay Katalin, Szakali Tibor (2012). Minimumelvárás ház̨ gyermekfelëgyeletben. Nemzeti Rehabilitációs és Szociális Hivatal, Budapest.

Kovácsné Bárány Ildikó, Mátay Katalin és Szombathelyiné Nyitrai Ágnes (2013): A családi napközi múkeödésének követelményei. Módszertani úmutató. Budapest.

Szombathelyiné Nyitrai Á.; Rózsa J.; Korintus M.né; Balogh L.né; Kissné Fazekas I.; Pósfai F.né (2008): A bölcsódei nevelés-gondozás országos alapprogramja. Budapest: Szociálpolitikai és Munkaügyi Intézet Gyermekvédelmi Főosztály.

Tardos Anna (1975): Neveléstan I. Egészségügyi Minisztérium, Budapest. 